い，延性，粒界挙動执よび破壊様式の温度とひずみ速度な どによる変化をしらべた，結果を要約するとつぎのよらに なる。

（1）銅の中間温度ぜい性は真空中に批いても大気中と本 質的に变わることなく生じる、すなわち，ぜい性は，低変 形速度で顕著に現われるが，変形速度の上昇とともに消隇 に向から。李た，断面收縮摔を尺度とした延性が極小を示 す温度は变形速度に関係しない。

（2）与兄られた温度および変形速度に㙏りる延性は，結 晶粒直径が $20 \mu$ を越すと急激低下し，粒直径が $80 \mu$ 以 上になると漂汪一定になる。

（3）中間鼬度ぜい性生起温度域に执いて，低速変形 ( $\left.110^{-3} / \mathrm{sec}\right)$ では, 試片はミクロ・ボイドの合体を伴ら粒 界分離によって破断したが，破面の態样は温度によって変 化した，中速変形 $\left(\simeq 10^{-1} / \mathrm{sec}\right)$ では，局部的な粒界分離に よって形成された空洞の閒のマトリックスの延性破壊が試 片を最終的に破断させた。ただし、このマトリックスの破 壊様式子温度に上って変化した，高速変形 $\left(\simeq 10^{2} / \mathrm{sec}\right)$ を
らけた試片は，全浊度域にわたって，粒界割れを生じるこ となく粒内延性破壊によって破断した。

おわりに，本論文の校閲委員 (複数)からとくに破面解析 について有益な示唆をいただいたことに感謝するととす に，走査電子顕微鏡観察に当ってご厚意をいただいたク レ・ノートン(株)ならびに同社技術部の林一郎氏に厚く 括礼申上げる。

\section{文献}

（1）大森正信，吉永芳豊，問庭芬比：金属学会誌，32 (1968), 686 .

（2）大森正信，旨永芳豊，間庭秀世：金属学会誌，34 (1970), 791 .

（3）大森正信，若㹨邦男，吉永芳豊：金属学会誌，37 (1973), 1188.

（4）大㷊正信, 若狭邦男：金属学会誌，37(1973)，1195.

(5) たとえば, R.T.Ratcliffe and G.W.Greenwood : Phil. Mag., 12(1964), 59.

(6) たとえば, R.D.Gifkins : Acta Met., 4(1956), 98.

(7) F.Garofalo: Ductility, ASM Metals Park, Ohio, (1967), 87.

\title{
引張変形した $\mathrm{Al}$ の局部収縮部の転位組織観察 ${ }^{*}$
}

$$
\begin{array}{lllllll}
\text { 芳 } & \text { 井 熊 } & \text { 安** } & \text { 大 } & \text { 洞 } & \text { 主*** } \\
\text { 川辺 } & \text { 秀 } & \text { 昭** } & \text { 山田 朝 } & \text { 治** }
\end{array}
$$

Kumayasu Yoshii, Yoshimasa Obora, Hideaki Kawabe and Tomoharu Yamada : Electoron Microscope Studies on the Structures Developed in the Necked Region of $\mathrm{Al}$ Specimens by Extension. Sheet specimens of high and commercial purity aluminum polycrystals were deformed in tension until the specimens necked and fractured. Strains of the necked region in the directions of the tensile axis, width and thickness of a specimen, that is, $\varepsilon_{l}, \varepsilon_{w}$ and $\varepsilon_{t}$, respectively, were measured from the appearance of the orthogonal grids scribed on the specimen surface. Dislocation structures in the necked region, strains of which were known, were also observed by means of electron microscope. The results are as follows:

(1) Specimens of high purity aluminum ruptured after 100\% reduction in area, and the measured values of $\varepsilon_{l}$ and $\varepsilon_{v}$ in the grids containing the fractured part were about $300 \%$ and $30 \%$, respectively. In the case of commercial purity aluminum the reduction in area was about $65 \%$, and $\varepsilon_{l}$ and $\varepsilon_{w}$ were about one-half of those in high purity aluminum.

(2) Pronounced cross-slips were observed on the surface of the necked region. Cell structures were formed in the regions of uniform deformation, necking and rupture. In the area unaffected by necking, cell structures were equi-axed having an average size of $3.5 \mu$ for high purity and $3 \mu$ for commercial purity aluminum, whereas in the necked region and the fractured part the cell structures were smaller in size and the dislocation densities in the cells increased.

(3) The cell size decreased linearly with increaseing reduction in area. Thus cell structures formed before the fracture has occurred seem to have a size of less than $2 \mu$ for high purity and $1.5 \mu$ for commercial purity aluminum. It could be imagined that fine cell structures in the necked regions result from the increase of cross-slips under two-dimensional stresses.

(Received November 25. 1975)

***大阪大学工学部(Faculty of Engineering, Osaka University, Suita)

****大阪大学大学完, 現在 : 株式会社小松製作所(Graduate School, Osaka University, Suita. Present address : Komatsu, Ltd., Tokyo)

* 1973 年 4 月金属学会東京大会に発表 


\section{I. 緒言}

金属材料の延性破塄の微視的機構を明らかにするために は，その過程を詳細に観察し把握する必要がある，破壞過 程を明らかにすることを目的とした研究は，軟鋼の塑性変 形中介在物に生したボイドの挙動を光学䁰微鏡により観察 した Tipper(1)に始まり，告の後電子顕微鏡や走査型電子 韭微鏡の発達ともあい委って多くの钼察結果が報告され， 基本的過程が徐々に解明されてきた。さらに転位諭的観点 から正性き裂の発生，伝ぱに対していくつかの転位機構 ${ }^{(2)}$ も提案されている。しかしこれらの結果は主として局部収

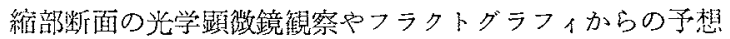
にすぎない，破壊に至る事での前駆現象として多量の塑性 变形を伴う局部収繀過程では，転位は重大な役割を演じて いると想像でさる。したかっって局部収繀部や破断部の下部 転位組織状態を明らかにすることる，延性破壊の微視的機 構の解明に必要なことと洘壳られる。

このよらな短点から促来, 延性金属薄膜の引張破壊過程 の透過電顕内連続䙿察 ${ }^{(3)(4)}$, 局部收縮部 ${ }^{(5)(6)}$ や延性破面直 下(7)の下部転位組織観察が行なわれている。著者らも透過

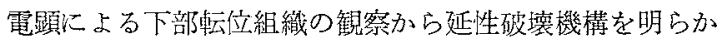
にすることを目的として, 典型的な姃性破填現象を示す高 純度 Al を用いて, 薄膜の引張破壊過程の透過電顕内連続 観察 ${ }^{\left({ }^{(8)}\right.}$ や薄板材の延性破断部近傍の下部転位組織観察 ${ }^{(8)}$ (9) を行なってきた。

本報では，高純度 $\mathrm{Al}$ 和よび敲業用 $\mathrm{Al}$ の多結晶板材を 引張変形乙，種々の断面減少率の局部収維部転位組織観察 を行ない，局部収縮に伴う微視組織の変化を検討した。

\section{II. 実 験 方 法}

\section{1. 供試材料および引張試験}

用いた試料は，綝度 $99.999 \%$ の高純度 $\mathrm{Al}$ と $99.5 \%$ の 㐭業用 Al の 2 種類の多綕晶材で方る。摩さ $1 \mathrm{~mm}$, 幅 10 $\mathrm{mm}$, 檪点間距離が $50 \mathrm{~mm}$ の板状試験片を作製した後, 真空中で $400^{\circ} \mathrm{C} \times 1$ hr の焼鏠を行ない引張䧕験に供した。

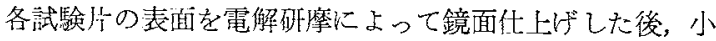

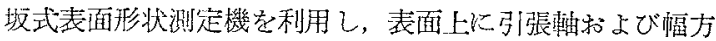
向に平行治 $500 \mu$ の間瀜でけがき，正方形の格子を作。 た。この試験片をインストロン引張試験機(TT-CM-L 型)

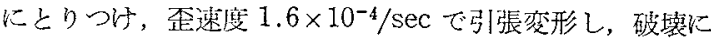
至るまでの琿々の段階で試験機のクロスへッドを停止さ せ，格子模様の変化を試験機に取付けた光学顕微鏡とカメ ラで撮影した。本実験では試験片各部における格子の引張 軸方向と幅力向の最初の長さ $l_{0}, w_{0}$ か 5 の变位量 $\Delta l, \Delta w$ を测定し，次式より各々の方向の歪量 $\varepsilon_{l} ， \varepsilon_{w}$ を求めた。

$$
\begin{aligned}
& \varepsilon_{l}=\Delta l / l_{0} \times 100 \quad(\%) \\
& \varepsilon_{w}=\Delta w / w_{0} \times 100(\%)
\end{aligned}
$$

また局部収縮領域の厚さ方向の変形量は，收緶後適当な時
点で除荷 $\mathrm{L} ， 小$ 服式表面形状測定機を用いて求まる收縮部 領域の断面形状から浿定した. Fig.1 はその方法を示し, (a)は測定機のトレース曲線の一例でありこの曲線によっ て均一変形部からのくほみ量 $t^{\prime}$ を測定し，(b)のごとく収 穛部領域の断面形状を描くことができる。ささらに次式から 厚さの減少摔 $\varepsilon_{t}$ を求めた。

$$
\varepsilon_{t}=\left(t_{0}-t+2 t^{\prime}\right) / t_{0} \times 100 \quad(\%)
$$

ここで $t_{0}$ は初期厚さ， $t$ は㚬一変形部の厚さである。

また断面減少摔 $R$. A . は,

R. A. $=\left\{1-\left(1-\varepsilon_{t} / 100\right)\left(1-\varepsilon_{w} / 100\right)\right\} \times 100 \quad(\%)$

占求めた。

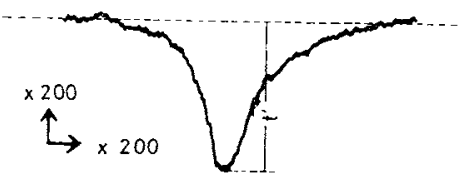

(a)

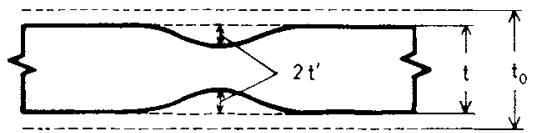

(b)

Fig.1 The process of measurement of the reduction in thickness. (a) trace curve by a roughness tester. $t^{\prime}$ is a depth from the surface of the region of uniform deformation, (b) sectional view of the necked region. $t_{0}$ is the initial and $t$ the present thickness of a specimen.

\section{2. 局暗收縮部の転位組織観察}

先に述べた方法によってお扰よ去の引張軸，幅力向の歪 和よび最大の断面減少率のわかった収維部から，Fig.2に 示すような方法で透過電顕観察用薄莫を作製した。まず予 储研摩として(a)のように試験片表面の片面から，収維部 領域をJet 研摩する。この祭研摩量が収縮部厚さの約半分 になるよらに研摩時間を調整した。(b)は予偉研摩後の試 験片形状を示している，次に裹面の一部々Jet 研摩した表 面を(c)のように絶縁塗料で覆い，短時間電解研杽学行な 5。このとき電流密度は絶縁塗料境界部で高くなり，断面 減少率最大の収縮部々境界部との交点Aは，他の場所より む一厢深く研摩され，次の仕上げ研摩で最初に小孔のあく

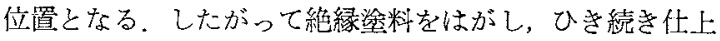
げ研摩を行ない，(d)のようにAの位置に小孔のあく僢間 に研摩を終了した、この研摩穴を中心以径が $3 \mathrm{~mm}$ 程度の 試料を，ワセリンで覆い電解研摩で無歪的に切り出し ${ }^{(8)}$, HU-500 型電顕により加速電左 $500 \mathrm{kV} て ゙$ 観察を行なった.

また破断部近傍の下部転位組織の観察には，厚さ $100 \mu$ の引張試験片の破断部を厚さ方向から透過電顕で検鏡し た。 


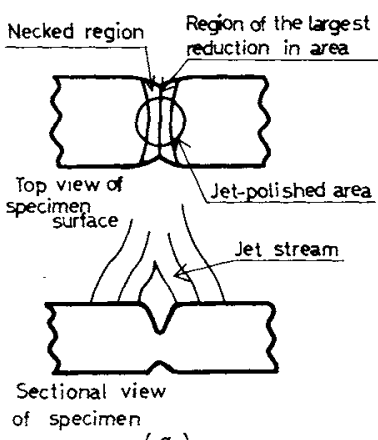

(a)
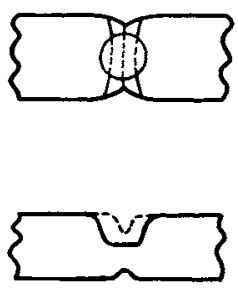

(b)

Fig.2 Procedures of preparation of thin foils from the necked region for transmission electron microscope. (a) jet-polishing, (b) after jetpolishing, (c) electrolytic polishing, (d) electrolytic polishing of both sides of the specimen surface until a hole appears.

\section{III. 結果および考察}

\section{1. 局部収縮部の下部転位組織}

高純度 $\mathrm{A} 1$ と商業用 $\mathrm{A} 1$ 各々の最大引張応力恬 $3.4,8.7$ $\mathrm{kg} / \mathrm{mm}^{2}$ ，破断需は $56 ， 47 \%$ であった。前節で述べたよう に試験片表面上の格子から試験片各部の歪量を求めた。

Fig.3 はそのような测定結果の高純度 A1 の場合の一例を 示し，最大の断面減少率を生じた領域を含导格子に注目 し，この格子の変形開始から破壊子での公称歪に対する $\varepsilon_{l}, \varepsilon_{t}, \varepsilon_{w}$ の変化を寒線で示した図である。ここで破線は均

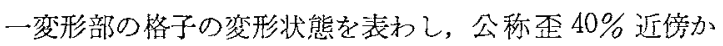
ら全く変化が見られず一定の值となっている。一方局部収 縮部の $\varepsilon_{w}$ は公称需とともにゆるやかに増加しているが， $\varepsilon_{l}, \varepsilon_{i}$ は公称霆 $40 \%$ 近倍から急激な堌加が始女り，特に破 断直前の公称歪 $50 \sim 60 \%$ の笧囲で増加の割合は大さくな る。破断部を含む格子の $\varepsilon_{l}$ は $300 \%$ 近くあり，破断面を 走查型電顕で観察した場合くさびの稜線として観察さ $れ^{(10)}, 100 \%$ の断面減少後に破断が生じたことがかかる. 商業用 $\mathrm{A} 1$ の場合も高継度 $\mathrm{A} 1$ の場合と同様な傾向を示し， 破断時の $\varepsilon_{l} ， \varepsilon_{w} ， \varepsilon_{i}$ は高純度 $\mathrm{Al}$ の場合よりも小さく、泀 半分以近心值上なった。 た破断面は延性破面特有の dimple patterm を是しており(10)，破盽時の断面減少率 は約 65\%であった。

Photo. 1 は局部収縮部の表面すべり線状態を観察した写

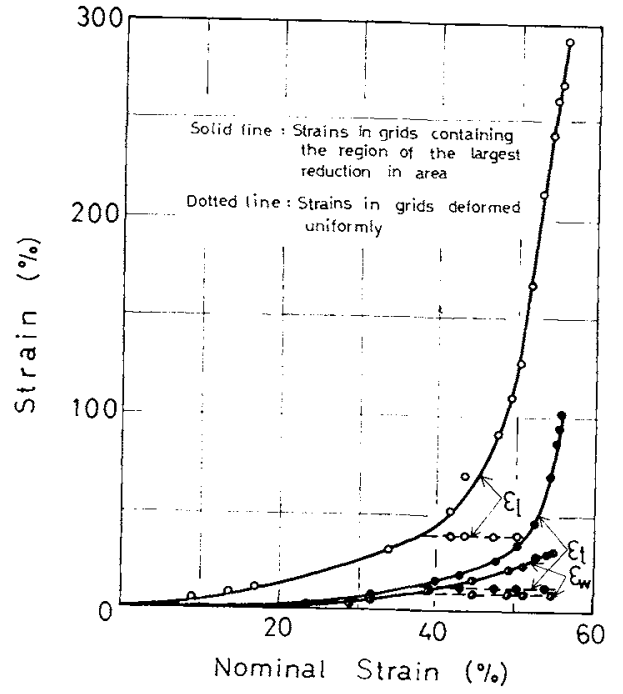

Fig.3 Strains $\left(\varepsilon_{l}, \varepsilon_{w}, \varepsilon_{t}\right)$ in the grids containing the region of the largest reduction in area and those in the grides deformed uniformly of high purity Al.
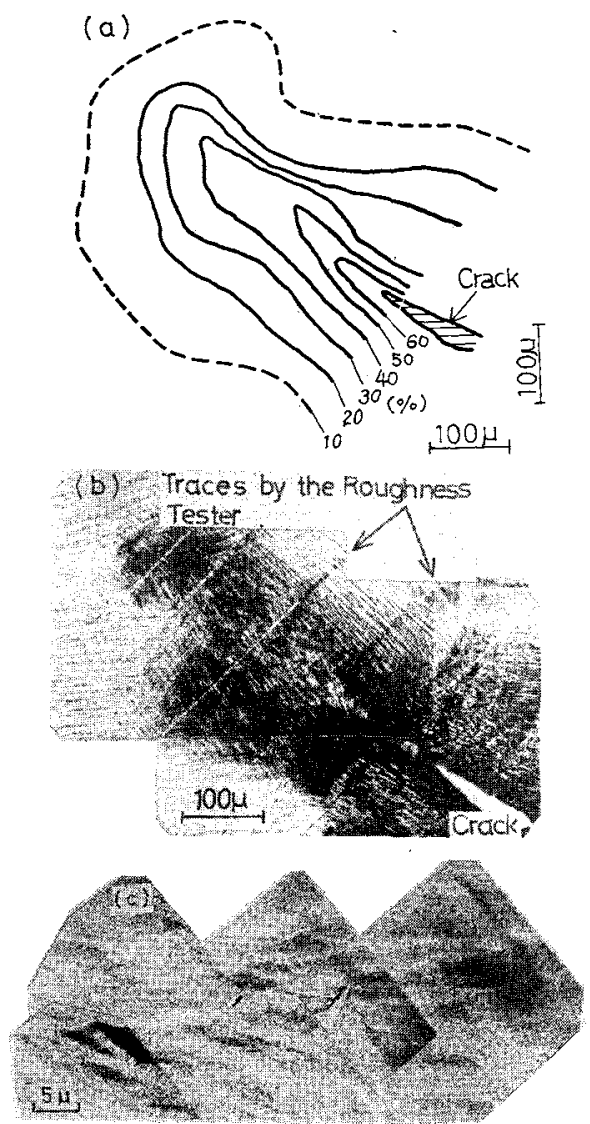

Photo.1 Observation of slip lines around a crack tip of high purity Al of $100 \mu$ thickness. (a) contour map of the reduction in thickness around a crack tip, (b) optical microscope observation around the same crack in (a), (c) replica observation of the severely deformed area. 
真で，約 $100 \mu$ 厚さの純 AI 板材を引張変形し生じたさ裂 先端近傍の (a) 表面形状测定機によって求めた涅さ減少率 等高線図，(b)光学頙微鏡突真支示している，(a)の収縮状 態厄対応してほほ同一領域に，均一变形部よりも激しく变 形した結果形成された強変形領域が見られる。(c)はこの 強変形領域のレプリカ写真で，すべり線が波状となってい ることから交差すべりが盛んに生じたことがわかる。

Fig.3, Photo.1 から Al の局部收繀部では，激しい交 差すべりによって均一変形部よりむ数倍以上の変形が生 じ，強変形領域が形成されることがわかった。均一変形 部，局部収緶部での下部転位組織の美暴を調べるために， 種々の取絔過程にある試料について，断面減少率最大を示 す収縮部和よび㚬一変形部の下部転位組織の観察を行なっ たＰhoto.2 は高紌度 Al の場合の観察例を示し，(a)，(b) は各々均一変形部と断面減少等約 $50 \%$ の局部収縮部の下 部転位組織である。市た Photo.3は，断面減少率が約 70 $\%$ の局部収縮部の観察写真である.A1は積層欠陷エネル ギが高いため，加工硬化の進展にともないセル組織が形成

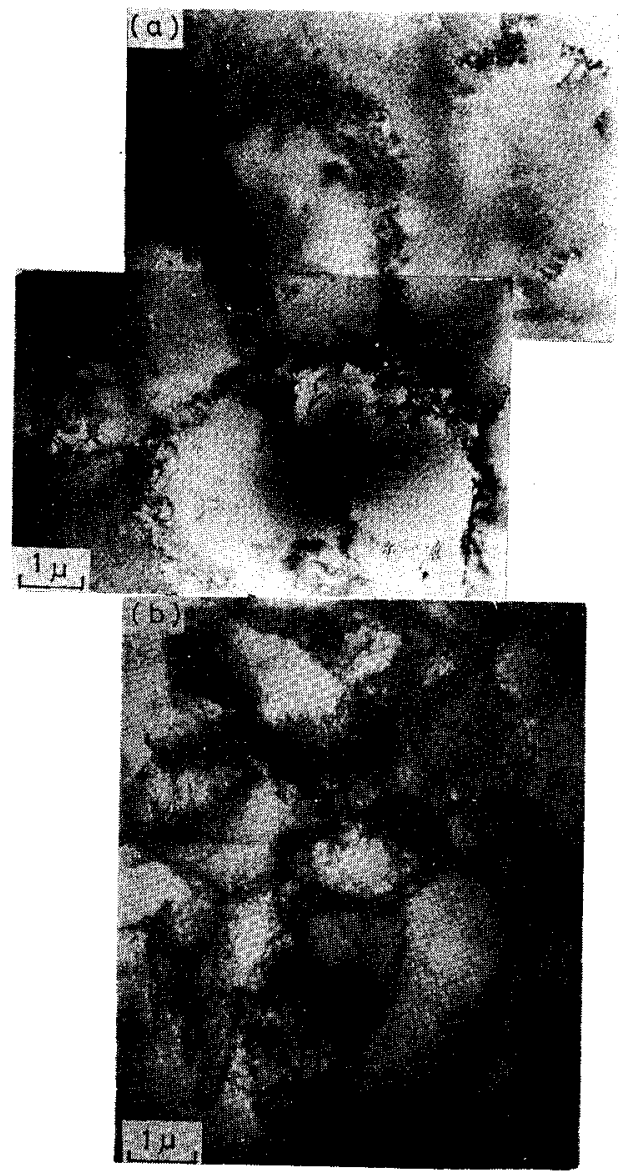

Photo.2 Dislocation structures in the necked region of high purity $\mathrm{Al}$. (a) dislocation structure in the region of uniform deformation (b) dislocation structure in the region of about $50 \%$ reduction in area.

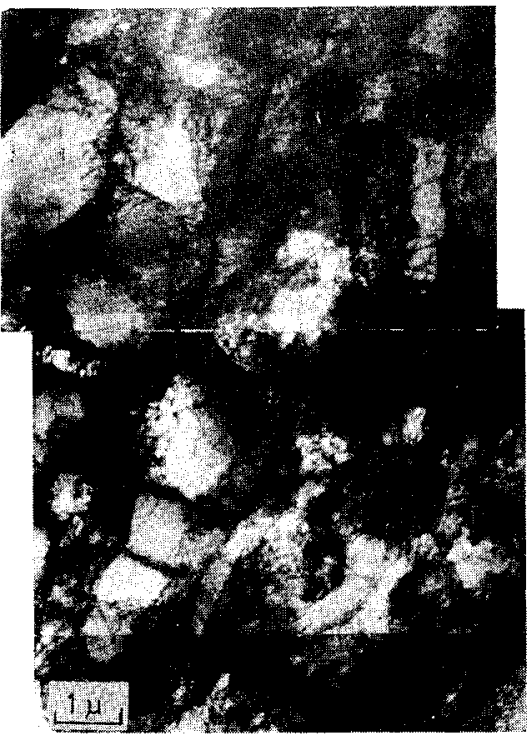

Photo.3 Dislocation structure of high purity $\mathrm{A} 1$ in the region of about $70 \%$ reduction in area.

される(11)，本実験に和いても均一変形部，局部収總部の 両領域ともに七儿組織が形成されている。 Lかし Photo.2

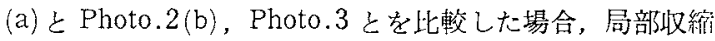

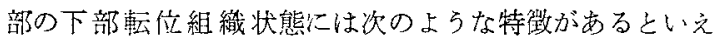

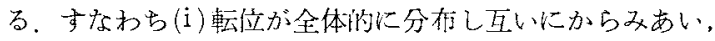
セル内転位密度は均一変抢部のを就に比べ 5 倍以上となっ ている。 (ii)したがって均一変形部の組織のように，セル 組織を明りょうに判別するのは困難であるが，姆一变形部

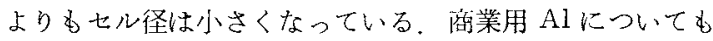
高純度 A1 の場合と同様な結杲が得られた。しかし何業用 Al には種々の形状，大きさの介在物が存在するために， 均一変形部や局部収縮部のセル径は高純度 $\mathrm{Al}$ に比べ小さ いな和収縮過程に礼いて介在物周辺に形成されるとい われているボイド(12)は，光学顕钽鏡では観察されたが， 電影では観察でさなかった。これは電解研摩過程に和

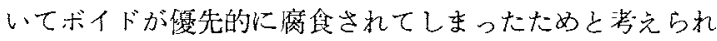
Ђ.

\section{2. 断面滅少率にともなうセル径の娈化}

$\mathrm{A} 1$ の引振りによって生じた均一変形部とその領域より もさらに多量の塑性変嫄をらけた局部収箱部とに心いて， セル組織が形成されていることがわかった，純 $\mathrm{Al}$ の引张 変形量と七ル径の関係についての Kelly\{13\}の報告によれ ば，七ルの大ささは变形初期に招いて急激に減少するが， 霆が $15 \%$ 以上になると約 $3 \mu$ の一定の值になる。本実験 において均一変形部のセル径が純 $\mathrm{Al}$ で約 $3.5 \mu$, 商業用 A1 で約 $3 \mu$ のセル組辅は一定のたル径に到達した結果で ある。このよらな動的回復段階にある均一変形部の七ル組 織の内の微小領域が大きい応力をらけるために，さらに組 
織変化が進行し局部収縮部の組織が形成されるといえる。

局部収縮部に関して収緶率と七儿径の関係を㛟討するた めに，種々の断面減少率に対する透過電影宣真から七ルの 大きさを測定した。各試料の局部収緢蔀から採取した薄膜

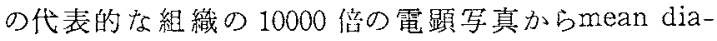
meter 法 ${ }^{(14)}$ によって七ル径の測定を行なった。この睖各 断面減少率に対するセル径の平均值を求めるのに数えた七 ルの個数は，100〜150で方る。この上らな測定結果から高

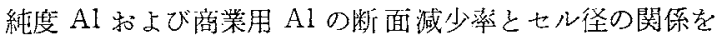
图示したのが Fig.4である。ここで断面城少率が約 20\% の平均セル径は，均一变形部のセルの大きさを表わしてい る。高純度 A1に出いてセル径は盽面減少率堌加とともに 直線的に減少寸る傾向にあり，断面減少率 $80 \%$ で約 $2 \mu$ の大ささになり，均一変形部の七ル徍より $1.5 \mu$ 以上も 小さくなっていることがわかる，唒策用 Al の場合む高純 度 A1 と同様に，断面減少率增玑とともにセ儿径は直線的 に減少してゆき，溯面減少率約 $60 \%$ で約 $1.5 \mu$ となっ いる，本実験では破皁部近傍から電解蹒摩によって電顕観 察用試料を採取することが困難であったため，破断部の下 部転位組織を観察していないしたがってその際のセル径 がFig.4の直線の延臣上にあるかは明らかでない。そこ で厚さ $100 \mu$ の純 $\mathrm{A} 1$ 多結晶板材の引張破断部を透過電顕 厄厚さ方向から観察した。その絬果をPhoto.4に示す.

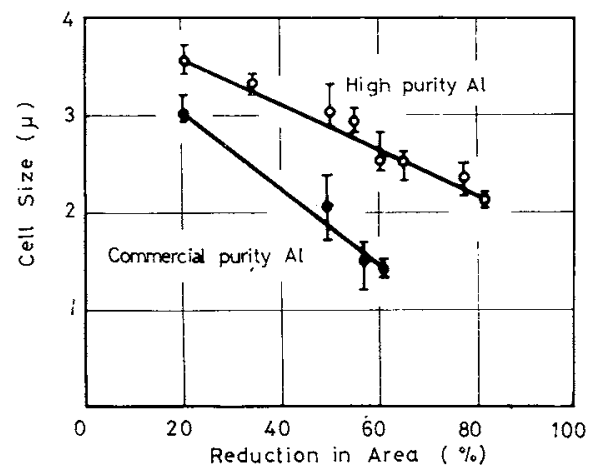

Fig.4 Relation between the cell size and reduction in area for Al polycrystals.

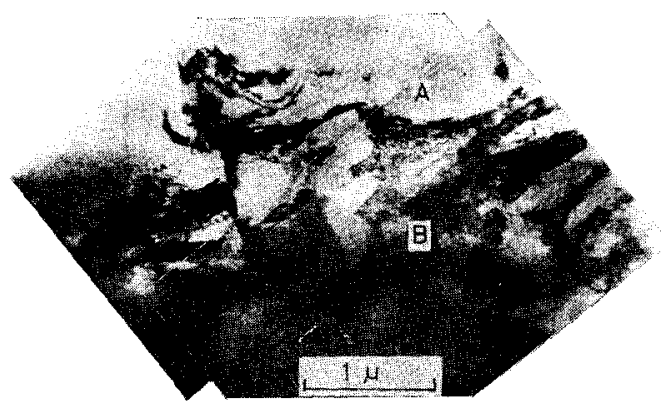

Photo.4 Fine cell structures near the fractured part of the sheet specimen of high purity Al polycrystals of $100 \mu$ thickness. A indicates the fracture teeth and $B$ the fine cell structures.
加速電肍 $500 \mathrm{kV}$ の透過電顕では透過性能が大きいので, 100\%断面減少し破断した破断部近傍の下部転位組織を,

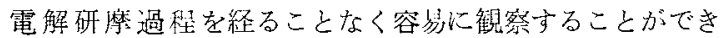
る(8). 破断部にAで示す晞さが $5000 \mathrm{~A}$ 以下゙の fracture

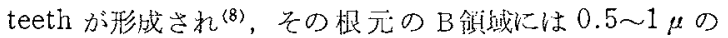
径を持つ微細なせル組織が存在している。また $0.2 \% \mathrm{C}$ $1.8 \% \mathrm{Mn}$ 鍓(7) の延性破面直下に\& $1 \mu$ 径以下の七ル組織

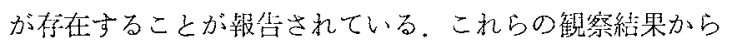

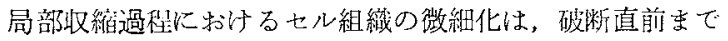
続くものといえる。

従来より七ル組織形成機構は電显権察などを通し種々提 案されているが(15)(16)，まだ十分にわかっているとはいえ ない、しかしいずれの機構においても多数のら世ん転位の 交差すべりが，七ル形成に対し重要な役割を活じているよ うである。純 Al 薄膜の引張变形過程の透過電顕内連続镜 察結果では，き裂先端などの二檕応力状態で夌差すべりの 碪度が增大し(17)，交差すべりしながら七ル内を転位が運 動しあらたなセル壁も形成される(8)。本尖験に虬いても局 部取維部表面にFhoto.1(c)で見るごとく激しい交差すべ りが生じていたことから，局部収繀開始とともに七ル組緎 を有与る微小部分に二韩応力が加わり，交差すべりの频度 が増大し收繀部の変形が進行するとともに，新しいセル壁 がつくられセル組織の微細化が進行すると考えられる，さ らに局部収繀部の組織形成に対し，収維部の企速度の增

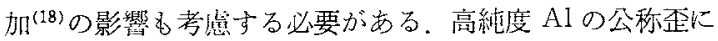

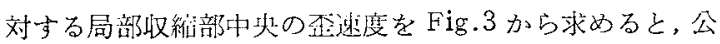
称整 45 50\% では約 $1 \times 10^{-1} / \mathrm{sec}, 50 \%$ 以上です $6 \times 10^{-1} /$

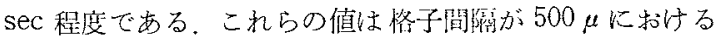

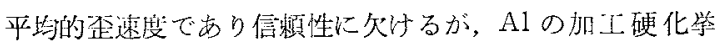

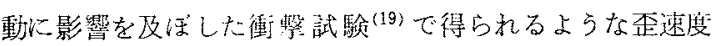
には至っていないようである。

本研究においてA1 の局部取維部の下部檕位組練を明ら かにした，局部収縮部では場所的に底打態や歪状態が異 なり均一ではない．したがって局部収維過程の加工硬化举 動を把握するためには，覞察した組織とその場所の応力分 布，雨分枋とを関連させ悇剖する必要がある。

IV. 総括

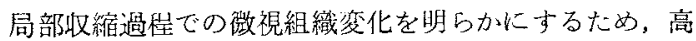

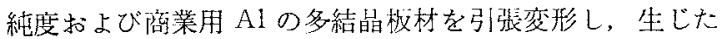
局部収維領域の引張軸，幅，倡さ方向の歪量 $\left(\varepsilon_{l}, \varepsilon_{w}, \varepsilon_{t}\right)$ を

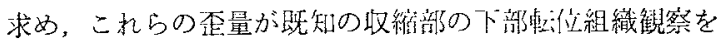
行なった。その結果，次の耤柄が明らかとなった。

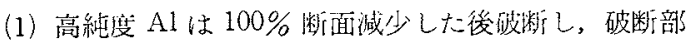
を含む格子の $\varepsilon_{l}$ は約 $300 \%$ ， $\varepsilon_{w}$ は $30 \%$ であった。一万䧄

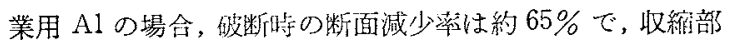
の変形量は高純度A1 の場合の約半分に近い值であった。

（2）多量の変形の生じた取紽部表面には強変形領域が形 成され，激しい交差すべりが観察された。 
（3）均一変形部，局部収縮部，破断部にはセル組織が形 成されていた。均一変形部でのセルの平均径は高純度 $\mathrm{A} 1$ に和いて $3.5 \mu$ ，商策用 Alに拈いて $3 \mu$ であった。一方 局部収繀部や破断部では均一変形部よりるセル径は小さ く，かつセル内の転位密度が上昇していた。

（4）取縮部の断面減少率に対するセル径の变化を秧討し た結果，破断直前では高純度 $A 1$ において約 $2 \mu$ ，滴業用 A1に和いて約 $1.5 \mu$ で, 断面減少率の上昇にともないて ル組織は直線的に微紬化する傾问にあった。その原因とし て，収縮部に作用する二軸応力のために，局部収縮領域で 転位の增殖や交善すべりの頻度が堌大したことが考えられ る.

本研究を遂行するに当り貴重な助言を賜わった東大物性 研竹内 伸助教授, 超高生電顕の操作に御協力いただきま した東大物性研鈴木邦大氏，市原正樹氏に深謝いたしま $\$$.

\section{文献}

(1) C.F.Tipper : Metallurgica, 39(1949), 133.

(2) D.C.McLean : Mechanical Properties of Metals, John Wiley, New York, (1962), 224.

(3) H.Saka and T.Imura : Japan. J.App1. Phys., 9 (1970), 1185.
(4) R.W.Bauer, R.H.Geiss, R.I.Lyles and H.G.F. Wilsdorf : Z. Metallk., $63(1972), 525$.

(5) G.Palmer, G.C.Smith and R.D.Warda : Conf. Proc. Physical Basis of Yield and Fracture, The Institute of Physics and The Physical Society, London, (1966), 53.

(6) 高瀬恭二：鉄と鋼，55(1969)，377.

(7) 南雲道彦：転位の素過程と複合過程(第 3 回)シンポ ジウム予稿，日本金属学会，(1974），5.

（8）芳井熊安, 多賀 豊, 川辺秀昭, 山田朝治: 材料, 24(1975), 520 .

(9) K.Yoshii, H. Kawabe and T.Yamada : Proc. 16 th Japan Cong. Materials Research, (1971), 1.

(10) K. Yoshii, H.Kawabe and T.Yamada: Inter. Conf.Mechanical Behavior of Materials, Vol. I (1972), 256.

（11）角野浩二：結晶の強度，朝倉畫店，東京，(1968）， 108.

(12) G. Y. Chin, W. F. Hosford, Jr, and W.A. Backofen: Trans. Met. Soc. AJME, 230(1964), 437.

(13) A. Kelly : Acta Cryst., 7 (1954), 554

(14) E. E. Underwood : Quantitative Stereology, Addison-Wesley, Mass., (1970), 91.

(15) A.Seeger : Dislocation and Mechanical Properties of Crystals, John Wiley, New York, (1956), 243.

(16) H.Fujita : J.Phys. Soc. Japan, $23(1967), 1349$.

(17) H.Fujita : J.Phys.Soc.Japan, 26(1969), 331.

(18) A.K.Ghosh : Met.Trans., 5(1974), 1607.

(19) 作井諴太，角間 孜，森兔：金属学会誌，29 (1965), 903.

\section{$\mathrm{Ir}-\mathrm{Mn}-\mathrm{Sb}$ 系における $\mathrm{Cl}_{\mathrm{b}}$ 型金属間化合物とその磁性についで}

\section{増本 量** 渡辺清** 大沼繁弘**}

Hakaru Masumoto, Kiyoshi Watanabe and Shigehiro Ohnuma : On a $\mathrm{Cl}_{\mathrm{b}}$-Type Intermetallic Compound in the Ir-Mn-Sb System and its Magnetic Properties. Crystal structures and magnetic properties of $\mathrm{Ir}-\mathrm{Mn}-\mathrm{Sb}$ alloys were studied through $\mathrm{X}$-ray and magnetic analyses. It has been found that the intermetallic compounds of the $\mathrm{Cl}_{\mathbf{b}}$-type structure exsist in the $\operatorname{IrMn}_{1+x} \mathrm{Sb}$ system and forms a solid solution in the composition range of $x=0.5 \sim 0.8$. $\operatorname{IrMn}_{1.5} \mathrm{Sb}$ and $\mathrm{IrMn}_{1.8} \mathrm{Sb}$ alloys of the $\mathrm{Cl}_{\mathbf{b}}$-type have lattice parameters of about 6.154 and $6.141 \AA$ at room temperature, magnetic moments $n_{B}$ of 2.6 and $2.1 \mu_{B}$ per $\mathrm{Mn}$ atom at absolute zero, and Curie temperatures $T_{c}$ of 278 and $258 \mathrm{~K}$, respectively. From the temperature dependence of reciprocal magnetic susceptibility $1 / x_{g}$, these $\mathrm{Cl}_{\mathbf{b}}$-type alloys are expected to change from the ferromagnetism to the ferrimagnetism with increasing $\mathrm{Mn}$ content.

(Received December 10, 1975)

\section{I. 緒言}

これ京でに強磁性あるいは反強磁性を示すPtMnSb(1) (2) PtMnSn(2)(3), AuMnSb(4), RhMnSb(5), PdMnTe ${ }^{(6)}$ 扰 びその他多くの $\mathrm{Mn}$ 基 $\mathrm{Cl}_{\mathrm{b}}$ 型金属間化合物 ${ }^{(7)}{ }^{(11)}$ が見出 されている。そしてこれら化合物の Mn 原子の位置は $\left(\frac{1}{4} \frac{1}{4} \frac{1}{4}, \frac{1}{4} \frac{33}{4}, \frac{3}{4} \frac{1}{4} 4, \frac{3}{4} \frac{3}{4} \frac{1}{4}\right), \mathrm{Mn}-\mathrm{Mn}$ 対の原子間 距離は約 $4.2 \sim 4.5 \AA$, 磁気モーメントは約 $4 \mu_{B}$ であっ て，これらの結晶構造と磁性が Heusier 型( L $22_{1}$ 型) 合金 $\mathrm{Cu}_{2} \mathrm{MnX}(12)(\mathrm{X}=\mathrm{A} 1, \mathrm{Ga}, \mathrm{In}, \mathrm{Sn})$ とく類似していること が明らかにされている。

** 財国法人電気磁気材料研究所(The Research Institute of Electric and Magnetic Alloys,

Yagiyama-minami 2, Sendai)

* 1969 年 10 月金属学会広島大会に発表; 財団法人電気磁気材料研究所研究報告第 95 号 